\title{
IDENTIFYING Risks FACING THE South AFRICAN TOURISM INDUSTRY
}

\author{
Gordon Shaw
}

UFH/ Sanlam in Entrepreneurship. University of Fort Hare

Melville Saayman

Institute for Tourism and Leisure Studies, North-West University, Potchefstroom

\author{
Andrea Saayman
}

School of Economics, North-West University, Potchefstroom

Accepted: February 2012

\begin{abstract}
Even though risks certainly influence travel and tourism patterns, very little research has been conducted into how the industry generally perceives and manages risks. This article aims to (i) identify the risks the South African tourism industry deems important; (ii) construct a matrix for assessing the various risks identified and (iii) determine whether sectors of the industry rate the importance of risks differently. In total, there were 212 responses to the questionnaire in the survey on South African tourism businesses. The statistical analysis included a factor analysis and an ANOVA (analysis of variance). Nine factors were identified and the ANOVA confirmed that sectors do perceive differing levels of importance in the various risks. The risk assessment matrix showed that internal risks are rated among the most important, even though little attention is paid to these in the literature.
\end{abstract}

Key words: risk management; factor analysis; tourism management; ANOVA

JEL: L83, G3

1

\section{Introduction}

Tourism is regarded worldwide as the industry with the highest growth rate and greatest potential for job creation (Business Day, 2004). Like any industry, however, it is susceptible to risk. Risks manifest in many forms, with disastrous consequences for the industry if they are not managed effectively (Lepp \& Gibson, 2003). This is especially true of developing countries (Burns, 1999). At the ITB Travel Trade Show on 11 March 2009, the then Secretary General of the United Nations World Tourism Organisation, Taleb Rifai, introduced his keynote speech by reiterating the greatest challenges that have faced world leaders during the past half century. Referring to risks such as the credit crunch, economic disarray, mounting unemployment and the recessionary reduction in market confidence, he expressed the opinion that no one knew how long these challenges would last (Rifai, 2009).

The current volatility of the world economy resulting from the financial crisis, rising prices in the commodity sector, the increasing price of oil and fluctuations in the exchange rate means that the tourism demand has slowed down significantly. A report released by the UNWTO (2009) made special mention of the number of international arrivals that had declined slightly during the second half of 2008, a trend that continued in 2009. The implication was that countries dependent on tourism, especially developing countries, would be the hardest hit by a major decline in travel. This would hold significant risk potential for tourism businesses, since it would signify a decline in the profitability of the tourism 
sector, leading in turn to insolvencies and job losses.

The survival of any business, including those in the tourism industry, depends on identifying and managing risks. This can be done either by eliminating the risk entirely, or, if this is not possible, by ensuring that any adverse impact that might occur will be kept to a minimum. Many risks can be transferred, for example, by means of insurance. But regardless of whether or not a risk can be transferred, it has to be identified if it is to be managed. Valsamakis, Vivian and du Toit (2004:3) cite management guru Peter Drucker's definition of risk management as 'the ability to manage the unexpected', while Gray and Larson (2006:208) define it as a proactive approach to minimising the negative consequences of undesirable events that may occur. The first step in risk management is therefore identifying potential risks (Valsamakis et al., 2004).

Kerzner (2001) reiterates that risk management and monitoring are not problem-solving techniques, but should be seen as proactive techniques for obtaining objective information to prevent the occurrence of adverse events or to minimise their negative impact. The complexities involved in risk management in the tourism industry mean that it must be seen as a process that requires constant review and updating. In the tourism industry, a risk existing outside the South African borders may represent an opportunity to be exploited for the benefit of the industry inside the borders. For example, the $9 / 11$ terrorist attacks in the USA had the effect of decreasing world tourist arrivals to 0 per cent, with arrivals to the USA declining by 4.7 per cent, while international travel to Africa increased by 3 per cent during the same year. Similarly, when elections were held in India in 2009, the India Premier League (IPL) - the most expensive cricket tournament in the world - was moved to South Africa because of terrorist threats, thus benefiting the South African tourism industry.

It is therefore important for businesses and the tourism industry in general to possess not only the ability to manage risk but also the skill and foresight to recognise it, since risk will have a tremendous bearing on the growth of the industry. Shaw (2010) goes so far as to maintain that the countries or destinations that manage risks best will have a competitive advantage. The purpose of the present research was, therefore:

- to identify the risks deemed important by the South African tourism industry (supply side);

- to construct a matrix for assessing the various risks identified; and

- to determine whether different sectors of the industry rate the importance of risks differently.

This is important, as risk management should be an ongoing process, seeing that it is critical to the sustained safety, security and well-being of the industry at both the local and the international levels.

The remainder of this article is structured as follows: Section 2 provides an overview of the literature on risks facing the tourism industry. This is followed by a description of the method of research followed in Section 3, and the results of the analysis in Section 4. In Section 5 the implications of the results for risk management in the industry are discussed, before the article concludes in Section 6.

\section{2}

\section{Literature review}

There are various definitions of 'risk'. The UNISDR (International Strategy for Disaster Reduction) defines it as 'the probability that a hazard will turn into a disaster', and goes on to say that 'Vulnerability and hazards are not dangerous, taken separately. But, if they come together, they become a risk or, in other words, the probability that a disaster will happen' (UNISDR, 2009). Kerzner (2001) suggests that risk involves lack of knowledge of future events, especially those events that have a negative impact on the business, also referred to as unfavourable events. Risk can be seen as the potential for loss or harm to an entity, where such an entity could be a person, a group, an organisation a system or a resource (Raval \& Fichadia, 2007). For example, technological risk means risks to information assets, such as unauthorised changes or modification of programs or data, theft of data and the unauthorised use of information assets. It can therefore be accepted that, if risk were 
not controlled and managed, the industry wold not grow and jobs would not be created.

Risk management is concerned with every kind of tourism industry business - tour operators, travel agents, hotels, lodges, game farms, bed and breakfast establishments, national, provincial and local parks, attractions, festivals, restaurants, airlines and guesthouses, to name but a few (see Figure 1). Most of these businesses are interdependent. For example, hotels, lodges, bed and breakfast establishments and guesthouses are dependent on numbers of tourists. At the same time, if these establishments could not provide sufficient accommodation, the number of tourists coming to the country would be curtailed. Other sectors, such as transport, the handling capacity of South African airports and harbours, and the services offered by the food and beverage and entertainment sectors increase the complexity, Should these not be effective and efficient the industry would suffer. Adding to the challenges to hand is the fact that a large percentage of tourism businesses are small, micro and medium enterprises (SMMEs). These businesses find it more difficult than the larger ones do to absorb some of the identified risks. Indeed, Saayman and Snyman (2005) have suggested that this is one of the drawbacks for SMMEs in the tourism industry.
Saayman and Snyman (2005) divide risks in the tourism industry into two categories: those that influence domestic travel and those that influence international travel. Examples of domestic travel risks are crime, fires, fraud, complaints, low-skilled staff, drop in turnover, bad marketing, poor maintenance of facilities and vehicles, bad management and various transport risks. These risks are present at the destination. Among the international travel risks are natural disasters (tsunamis, hurricanes, drought), socio-demographics (ageing markets, family life-cycles and changing structures), economics (recessions, increase in oil prices, exchange rates), politics (sanctions, terrorism) and disease (H1N1-virus, HIV/AIDS, SARS, Ebola). Even though these risks may be present outside the borders of a destination they nevertheless affect travellers to that destination. What makes it difficult for the tourism industry to determine the overall effect of risk is the fact that not just one company is involved, but rather a whole industry or destination, which is usually made up of many attractions and businesses. Figure 1 shows the flow of risk relating to the tourism industry. For example, risks affecting game farms might pose no risk at all for hotels or other establishments. Risks differ from one sector of the industry to the next.

Figure 1

The flow of risks

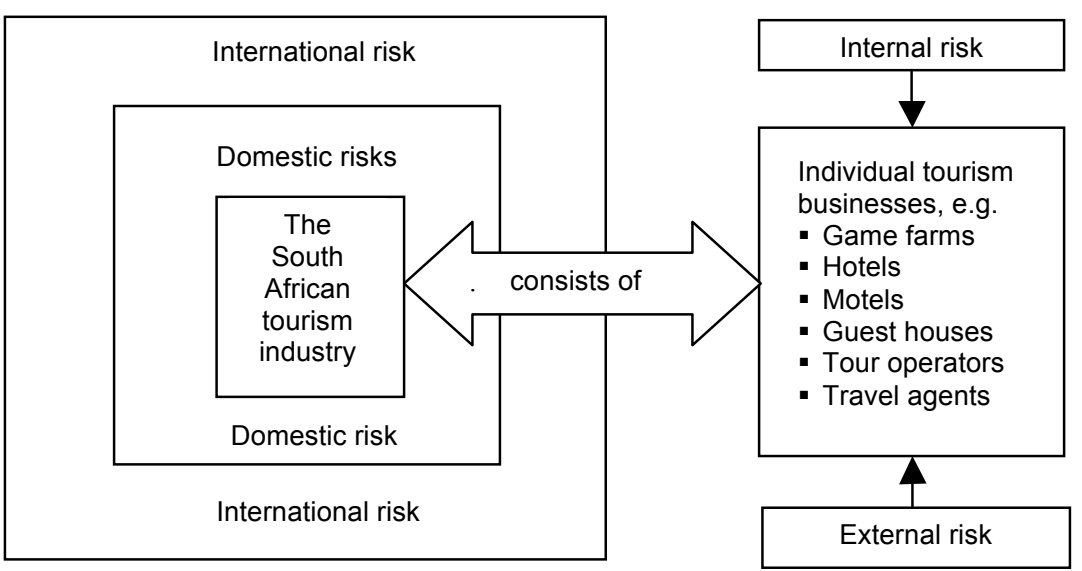


A number or authors have identified risks relating to tourism and the tourism industry, although the focus has been largely on external risks (i.e. risks that are beyond the control of management - see Table 1). However, tourism businesses also face normal internal operational risks. Central to these internal risks is the lack of properly-trained staff, which creates a gap in the skills needed for identifying and managing these risks. Özükan (2009) says it is not easy to provide human resources for the tourism industry because, even though unemployment is at peak levels, 'we have been unable to find qualified people for the serviceintensive tourism business'. The lack of qualified staff is thus seen to be limiting the growth of the tourism industry. The risks faced by the industry are summarised in Table 1.

Even though Table 1 makes reference to a considerable number of studies conducted on risk in the tourism industry, it is evident that very few researchers have investigated risk from the point of view of supply. Studies such as those by Lepp and Gibson (2003) considered risk from the perspective of demand, indicating that different groups of people, based on tourist role, gender and experience, view different risks as important. Most other studies on this topic have addressed specific risks such as crime and natural disasters and their impact on the tourism industry. The literature review revealed that the following risks were making a significant impact on travel and tourism. In terms of natural disasters, the South African Weather Service found that floods, tornadoes and droughts made a significant impact (SAWS, 2008). Moll (2008) found that fires, especially veld fires, had a negative effect, not only because they destroyed attractions but also because the recovery rate was usually slow and expensive. A tsunami, although occurring rarely, naturally has catastrophic consequences: 240000 people, many of them tourists, were killed in the tsunami that struck Thailand, Indonesia and the Philippines in 2004.

\section{Table 1}

Risk categories associated with tourism and the tourism industry

\begin{tabular}{|c|c|}
\hline Risk category & Description and reference \\
\hline Nature & $\begin{array}{l}\text { - Natural disaster - Abbott (1996); Hystad and Keller (2008); National Hurricane Center (2005); } \\
\text { - Weather and climatic conditions - Ehmer and Heymann (2008); Met Office (2007); SAWS (2008); } \\
\text { - Environmental factors - Hystad and Keller (2008); Page (2007); }\end{array}$ \\
\hline Crime and safety & $\begin{array}{l}\text { - Fraud and crime - Brunt, Mawby and Hambly (2000); Dimanche and Leptic (1999); Garcia and } \\
\text { Nicholls (1995); Hall, Selwood and McKeown (1995); Moore and Berno (1995); Pizam, Tarlow } \\
\text { and Bloom (1997); Raynor and Robinson (2005); } \\
\text { - Acts of terrorism and hijacking - Aziz (1995); Bar-On (1996); Enders, Sandler and Parise (1992); } \\
\text { Leslie (1999); Richter and Waugh (1986); Sönmez (1998); Sönmez and Graefe (1998); Sönmez, } \\
\text { Apostolopoulos and Tarlow (1999); Wagner, Apostolopoulos and Tarlow (1999); }\end{array}$ \\
\hline Health & $\begin{array}{l}\text { - Infectious diseases - Carter (1998); Cossens and Gin (1994); Lawton and Page (1997); Vellas } \\
\text { and Becherel (1995); WHO (2006, 2008) } \\
\text { - Malaria - Carter (1998); Lawton and Page (1997); WHO (2006, 2008); }\end{array}$ \\
\hline Political factors & $\begin{array}{l}\text { - War - Ellis (1995); } \\
\text { - Political instability - Aziz (1995); Bar-On (1996); Enders et al. (1992); Leslie (1999); Richter and } \\
\text { Waugh (1986); Sönmez (1998); Sönmez and Graefe (1998); Sönmez et al. (1999); }\end{array}$ \\
\hline Economic factors & $\begin{array}{l}\text { - Lack of funding - Hill (2002); Page (2007); Raval and Fichadia (2007); } \\
\text { - Exchange rates - Hill (2002); Oxelheim and Wihlborg (1998); Saayman (2008); } \\
\text { - Rising prices - Hill (2002); Oxelheim and Wihlborg (1998); Page (2007); } \\
\text { - Economic recession - Hill (2002); Oxelheim and Wihlborg (1998); } \\
\text { - Trancial crises - Oxelheim and Wihlborg (1998); Raval and Fichadia (2007); }\end{array}$ \\
\hline Technology & $\begin{array}{l}\text { - Information technology (IT) - Dorf and Byers (2008); Jacobson, Booch andRumbaugh (1999); } \\
\text { Jordan and Silcock (2005); Raval and Fichadia (2007); Rayner (2003); } \\
\text { - Reservation systems - Jordan and Silcock (2005); } \\
\text { - Computer programs - Jordan and Silcock (2005); }\end{array}$ \\
\hline $\begin{array}{l}\text { Socio-demographic } \\
\text { factors }\end{array}$ & $\begin{array}{l}\text { - Age - Krippendorf (1987); State and Nedelea (2008); Tretheway and Mak (2006); } \\
\text { - Sex - Krippendorf (1987); Tretheway and Mak (2006); } \\
\text { - Family life - Krippendorf (1987); Tretheway and Mak (2006); } \\
\text { - New markets - State and Nedelea (2008); Tretheway and Mak (2006). }\end{array}$ \\
\hline
\end{tabular}


Ehmer and Heymann (2008) are of the opinion that climatic change will also affect the African continent most seriously, thus posing a significant risk in the future. When it came to market changes, Saayman (2008) and State and Nedelea (2008) found that ageing markets and changing family structures posed serious risks for the tourism industry and future markets. Coupled with this, competition among destinations for the same key markets is increasing. According to Carter (1998), Cossar (1996), Cossins and Gin (1994) and the Public Health Agency of Canada (2009), the risk associated with health issues is having a significant effect on the tourism industry. Tuberculosis and HIV/AIDS have been identified by the US Agency for International Development (USAID, 2009), while cholera and malaria have been identified by the World Health Organisation (WHO, 2008) and Hadebe (2009) as major health risks. However, Schonteich (2000) suggests that crime is the greatest risk for tourism in many countries, especially developing countries, which is corroborated by Abbott (1996) and the United Nations (UN 2005). In addition, terrorist attacks are on the increase and have serious implications, as pointed out by Aziz (1995), Enders et al. (1992), Ria Novosti (2010), Sönmez (1998) and Sönmez and Graefe (1998).

Economic risks for tourism are well documented in the literature. The following serve as examples: Dwyer, Forsyth and Rao (2000), Durbarry and Sinclair (2003) and Gu (1995) on interest rates and tourism activities; Oxelheim and Wihlborg (1998) on exchange rates and tourism; Moffett, Stonehill and Eiteman (2008) on increased transport cost and travel; Nxumalo (2009) on recessions and tourism; and Smith (2006) on the importance of disposable income for tourism. Research into internal business risks covers aspects such as fraud (Goss 2003) and the lack of funding and properly-trained staff (Saayman \& Snyman, 2005).

However, for purposes of the literature review, no study could be found that addressed domestic and international risks in the South African tourism industry from the perspective of supply - in other words, what product owners and entrepreneurs view as key risks. It became clear that the tourism industry is highly susceptible to risk and that the list of risks seems to be virtually without limit. There is also the impression that the tourism industry in general tends to be reactive rather than proactive in addressing risks, producing many impact evaluations but few risk forecasts; this is despite the fact that Shaw (2010) states that the frequency and scope of risks across the globe have increased significantly during the past two decades.

\section{3}

\section{Method of research}

\subsection{Empirical survey}

The objective of the survey, using a structured questionnaire, was to discover what the respondents considered to be risk on a descending Likert scale: extremely high risk (5), high risk (4), moderate risk (3), low risk (2), extremely low risk (1). The questionnaire measured the importance (i.e. the weight) each respondent attached to each risk-element identified.

The questionnaire was structured in two sections. Section A asked for institutional information, including the type of business, the province in which the business was situated, the educational level of the owner or operator, the method of determining and evaluating business risks, and the key factors considered important when determining risk. Section B consisted of 57 statements related to risk intensity. Care was taken to ensure that the statements covered all the risk categories identified in the literature (see Table 1). Internal operational risks (based on management literature) not normally found in international case studies on tourism risks were also included.

\subsection{Sampling and survey method}

The target population was comprised of transport providers, tour operators, travel agents, destination management companies, suppliers of accommodation (i.e. hotels, lodges, bed-andbreakfast establishments and guesthouses), tourism brokers, suppliers of adventure tourism, business tourism suppliers and tourism service providers. Approximately 800 members out of 
an estimated 1200 were randomly requested to complete questionnaires. For a population size of 1000 , a sample of 286 is sufficient, given a 5 per cent level of confidence, while a sample of 333 is sufficient for a population of 2000 (with 5 per cent confidence) (see Yamane, 1967). 800 is therefore a sufficient sample size for the population. Databases of the Association of South African Travel Agents (ASATA) and the South African Travel Services Association (SATSA) were used, as these two organisations represent the interests of most operators in the South African tourism industry. Two further reasons for this choice were that members of the tourism industry are generally reluctant to complete questionnaires, and that by using the total population as defined by SATSA and ASATA, the resulting databases would ensure a high degree of relevant representation.

Response was slow, as had been anticipated, so a second request was sent out. Overall, 254 questionnaires were returned. This equates with a response rate of 31.75 per cent, which is considered satisfactory for this type of survey (Cooper \& Schindler, 2001:314). Of the responses received, 212 (26.5 per cent of the 800 questionnaires sent out) had been completed satisfactorily and could be used for analysis. A breakdown of the sample and responses by business operator or owner is given in Table 2.

Table 2

Sample and response

\begin{tabular}{|l|c|c|c|}
\hline \multicolumn{1}{|c|}{ Type of business } & Population & \multicolumn{2}{c|}{ Response } \\
\cline { 2 - 4 } & $\%$ & No. & \% of Response \\
\hline Tour operators & 24.80 & 63 & 29.72 \\
\hline Guesthouses & 14.96 & 38 & 17.92 \\
\hline Bed \& breakfast establishments & 12.99 & 33 & 15.57 \\
\hline Travel agents & 12.60 & 32 & 15.09 \\
\hline Lodges & 9.06 & 23 & 10.85 \\
\hline Hotels & 4.72 & 12 & 5.66 \\
\hline Other & 4.33 & 11 & 5.19 \\
\hline Spoilt responses & 16.54 & 42 & $\mathrm{n} / \mathrm{a}$ \\
\hline Total & 100.00 & 254 & $\mathrm{n} / \mathrm{a}$ \\
\hline Total valid responses & $\mathrm{n} / \mathrm{a}$ & 212 & 100.00 \\
\hline
\end{tabular}

As can be seen from Table 2, the highest percentage of tourism businesses participating in the survey were tour operators (29.72 per cent), while the lowest response rate was from hotels (5.66 per cent). Compared with the distribution of the population across the different types of business, the response distribution more successfully captured the main categories of the population. The responses received were therefore not expected to be biased towards one particular business segment of the industry. The distribution of the sample as measured over all nine provinces of South Africa is shown in Table 3. Again, the population distribution was used as the benchmark against which the distribution of the responses was assessed.

The number of responses reflected in Table 3 is higher than the 212 valid questionnaires because some of the businesses are situated in more than one province, which the respondent indicated on the questionnaire. Every province was therefore sampled, with the major tourist areas, the Western Cape, Gauteng, KwaZuluNatal and Mpumalanga, representing the bulk of the tourism industry. The response is thus, as indicated below, a reasonably good representation of tourism businesses in South Africa.

\subsection{Statistical methods}

Microsoft $\subset$ Excel $\subset$ was used for capturing the data, and basic data analysis and SPSS (SPSS Inc., 2007) were used for the further analysis. The Kaiser-Meyer-Olkin measure of sampling adequacy was then used to determine whether the covariance matrix was suitable for factor analysis. Kaiser's criteria were used to extract 
all the factors with Eigen values larger than one, because they are considered to explain a significant amount of variation in the data (Pallant, 2007). A factor analysis was used to identify sub-groups of risk through a combination of attributes. The factor analysis included an Oblimin rotation with Kaiser normalisation. Additional analyses used included an analysis of variance (ANOVA) and Tukey's post hoc test, to determine whether the responses of the various tourism businesses differed from each other.

Table 3

Provincial distribution

\begin{tabular}{|c|c|c|c|}
\hline \multirow{2}{*}{ Province } & \multirow{2}{*}{$\begin{array}{c}\text { Population } \\
\%\end{array}$} & \multicolumn{2}{|c|}{ Response } \\
\hline & & No. & $\%$ of response \\
\hline Western Cape & 25.38 & 81 & 29.24 \\
\hline Gauteng & 22.00 & 70 & 25.27 \\
\hline KwaZulu-Natal & 15.38 & 49 & 17.69 \\
\hline Mpumalanga & 7.50 & 24 & 8.66 \\
\hline Eastern Cape & 6.00 & 19 & 6.86 \\
\hline Limpopo & 3.75 & 12 & 4.33 \\
\hline Free State & 2.38 & 8 & 2.89 \\
\hline North West & 2.25 & 7 & 2.53 \\
\hline Northern Cape & 2.25 & 7 & 2.53 \\
\hline Spoilt responses & 13.11 & 42 & $\mathrm{n} / \mathrm{a}$ \\
\hline Total & 100.00 & 319 & $\mathrm{n} / \mathrm{a}$ \\
\hline Total valid responses & $\mathrm{n} / \mathrm{a}$ & 277 & 100 \\
\hline
\end{tabular}

\section{4 \\ Results}

The results are discussed in two sections. The first discusses the results of the factor analysis and the second uses ANOVA and Tukey's post hoc test to compare the importance of the identified risks for the various sectors of the tourism industry.

\subsection{Factor analysis}

The 57 statements in the structured questionnaire, based on the seven risk categories in Table 1, were subjected to a factor analysis to identify the various risk categories and the items that defined them. Bartlett's test of specificity yielded $p$-values of $<0,001$, which indicates that the correlation structure is valid for factor analysis of the data collected.

Nine factors were identified, accounting for 60 per cent of the total variance (see Table 4). All the factors had relatively high reliability coefficients, ranging from 0.35 to 0.93 . Although a reliability coefficient of 0.35 is low, as there are only two risks included in this factor, all other reliability coefficients were above 0.63 (one factor) and the other seven were equal to or greater than 0.82 . This indicates that, overall, except for Factor 7 (health risks), the results are reliable. The average inter-item correlation coefficients with values between 0.15 and 0.69 also imply internal consistency for all factors. Moreover, all items loaded on a factor with loading greater than 0.3. Relatively high factor loadings indicate a reasonably high correlation between the delineated factors and their individual items. The Kaiser-Meyer-Olkin measure of sampling adequacy of 0.87 also indicated that the patterns of correlation were relatively compact and should yield distinct and reliable factors (Field, 2005).

The results of the factor analysis show the relative importance of the perceived risk to the tourism industry operator by means of the mean value for each factor. A higher mean value implies a higher perceived risk. Within each factor, the individual items (risks) were ranked in order of the strength of relationship between the item and the factor, from high to low, by means of the factor loading. The importance of perceived risk increases as the value of the factor loading increases. The results for each factor are shown in Table 4 .

Seven of the nine factors are external risks and two, namely business insufficiencies and 
operational risk, are internal. The results shown in Table 4 reveal that the risks with the highest mean values are: national image and competitiveness (3.27), affordability and safety (3.18), and economic risks (3.12). This is not surprising, seeing that these are all external risks over which owners or managers have no control. However, an analysis of these top three risks makes it clear that the national image and competitiveness risks involve aspects that influence accessibility, such as basic infrastructure and marketing or the lack thereof. Affordability and safety involve considerations such as the exchange rate and personal safety and security. Many of these are within the ambit of government. Even the third-highest rated risks, economic risks, are influenced specifically by government's monetary policy (interest rates and inflation). At the other end of this scale it is interesting to note that the respondents do not regard health risks as major, as this factor received a mean value of 2.11 out of 5 in terms of importance; this was despite the fact that southern Africa (including South Africa) has high rates of HIV/AIDS and is struggling to combat tuberculosis, while central Africa is regularly threatened by Ebola outbreaks.

Table 4

Summarised factor analysis results

\begin{tabular}{|c|c|c|c|c|}
\hline Risk Items & $\begin{array}{l}\text { Factor } \\
\text { loading }\end{array}$ & Mean value & $\begin{array}{l}\text { Reliability } \\
\text { coefficient }\end{array}$ & $\begin{array}{c}\text { Average } \\
\text { inter-item } \\
\text { correlation }\end{array}$ \\
\hline \multicolumn{2}{|l|}{ Factor 1: Operational risk } & 2.29 & 0.93 & 0.49 \\
\hline Range of products & 0.806 & & & \\
\hline Customer complaints & 0.792 & & & \\
\hline Non-performance with compliance policy & 0.755 & & & \\
\hline Amount of overtime worked by employees/employee errors & 0.753 & & & \\
\hline Number of temporary personnel & 0.738 & & & \\
\hline Vacation & 0.729 & & & \\
\hline Employee turnover & 0.700 & & & \\
\hline Lack of quality service & 0.574 & & & \\
\hline Repeat business & 0.570 & & & \\
\hline Inability to fulfil needs & 0.476 & & & \\
\hline Theft in business by tourists & 0.422 & & & \\
\hline Technological changes & 0.370 & & & \\
\hline \multicolumn{2}{|l|}{ Factor 2: Environmental (nature) } & 2.47 & 0.85 & 0.48 \\
\hline Water pollution & 0.814 & & & \\
\hline Air pollution & 0.807 & & & \\
\hline Availability of drinking water & 0.713 & & & \\
\hline Urbanisation & 0.515 & & & \\
\hline Seasonality & 0.372 & & & \\
\hline \multicolumn{2}{|l|}{ Factor 3: Affordability \& safety } & 3.18 & 0.82 & 0.36 \\
\hline Exchange rate & 0.754 & & & \\
\hline Currency fluctuations & 0.681 & & & \\
\hline Airline safety & 0.547 & & & \\
\hline Increased international competition & 0.538 & & & \\
\hline Airport safety & 0.537 & & & \\
\hline Crime & 0.530 & & & \\
\hline Increased competition nationally & 0.354 & & & \\
\hline Change in tourist needs & 0.277 & & & \\
\hline \multicolumn{2}{|l|}{ Factor 4: Crime \& political factors } & 2.71 & 0.83 & 0.49 \\
\hline Wars/conflicts & 0.782 & & & \\
\hline Terrorist activities & 0.764 & & & \\
\hline Natural disasters & 0.578 & & & \\
\hline
\end{tabular}




\begin{tabular}{|c|c|c|c|c|}
\hline Political instability in South Africa & 0.548 & & & \\
\hline Political instability in neighbouring states & 0477 & & & \\
\hline Fire & 0.403 & & & \\
\hline Climate change & 0.397 & & & \\
\hline Theft/fraud & 0.277 & & & \\
\hline Factor 5: National image and competitiveness & & 3.27 & 0.82 & 0.33 \\
\hline National marketing & 0.686 & & & \\
\hline Insufficient marketing by local authorities & 0.679 & & & \\
\hline Image of country & 0.558 & & & \\
\hline Legislation & 0.430 & & & \\
\hline Road safety & 0.418 & & & \\
\hline Electricity cuts & 0.398 & & & \\
\hline Decrease in disposable income & 0.364 & & & \\
\hline Lack of municipal services & 0.363 & & & \\
\hline Prices too high & 0.350 & & & \\
\hline \multicolumn{2}{|l|}{ Factor 6: Business insufficiencies } & 2.83 & 0.84 & 0.51 \\
\hline Insufficient funding for training & 0.776 & & & \\
\hline Lack of qualified staff & 0.772 & & & \\
\hline Lack of experienced staff & 0.760 & & & \\
\hline Lack of funding for product development & 0.586 & & & \\
\hline Ageing markets & 0.468 & & & \\
\hline Lack of proper financial system & 0.278 & & & \\
\hline \multicolumn{2}{|l|}{ Factor 7: Health risk } & 2.11 & 0.35 & 0.15 \\
\hline Diseases & 0.753 & & & \\
\hline HIVIAIDS & 0.688 & & & \\
\hline \multicolumn{2}{|l|}{ Factor 8: Economic risk } & 3.12 & 0.63 & 0.46 \\
\hline Inflation & 0.763 & & & \\
\hline Interest rates & 0.750 & & & \\
\hline Decreasing leisure time for tourists & 0.291 & & & \\
\hline \multicolumn{2}{|l|}{ Factor 9: Transport risk } & 2.88 & 0.82 & 0.69 \\
\hline Increase in cost of fuel & 0.455 & & & \\
\hline Carrying capacity & 0.371 & & & \\
\hline BEE & 0.285 & & & \\
\hline Cost of transport & 0.258 & & & \\
\hline
\end{tabular}

\subsection{ANOVA and Tukey's post hoc tests}

To determine whether there was any significant difference between the mean responses by the various businesses that comprised the sample, an ANOVA was applied. Tukey's post hoc tests for unequal sample sizes were then performed on the factors that differed significantly from the others to determine where this difference lay. The ANOVA results are shown in Table 5, where it is evident that there were significant differences $(p<0.05)$ between the various businesses' views on the importance of factors 3 (affordability and safety) and 7 (health). For three other factors, 1 (operational risk), 6 (business insufficiencies) and 9 (transport risk), there were also moderate differences between the various businesses $(p<0.1)$; these five factors therefore warranted investigation.

Tukey's post hoc test indicated that:

i) Tour operators and travel agents are more inclined than other tourism businesses, especially bed and breakfast establishments and guesthouses, to regard affordability and safety risks as important, presumably because the nature of their businesses makes them more vulnerable to the risk items comprising this factor. The smaller establishments are less likely to attract international business and therefore are not as strongly influenced by considerations such as airline safety, crime, and currency fluctuation. 
Table 5

Analysis of variance

\begin{tabular}{|c|c|c|c|c|c|c|c|c|}
\hline \multicolumn{9}{|c|}{$\begin{array}{l}\text { Analysis of Variance } \\
\text { Marked effects are significant at } p<0.05000\end{array}$} \\
\hline Variable & SS effect & df effect & MS effect & SS error & df Error & MS Error & $\mathbf{F}$ & Prob. \\
\hline Operational risk & 6.75194 & 5 & 1.350389 & 122.2907 & 184 & 0.664624 & 2.031810 & $0.076^{*}$ \\
\hline Environmental & 1.58417 & 5 & 0.316834 & 160.3317 & 184 & 0.871368 & 0.363605 & 0.872 \\
\hline Affordability \& safety & 25.83019 & 5 & 5.166037 & 102.1383 & 184 & 0.555100 & 9.306503 & $<0.001^{* * *}$ \\
\hline Crime \& political factors & 4.41873 & 5 & 0.883746 & 166.3403 & 184 & 0.904024 & 0.977570 & 0.432 \\
\hline $\begin{array}{l}\text { National image \& } \\
\text { competitiveness }\end{array}$ & 5.08514 & 5 & 1.017029 & 106.8992 & 184 & 0.580975 & 1.750557 & 0.125 \\
\hline Business insufficiencies & 7.12044 & 5 & 1.424088 & 130.5025 & 184 & 0.709253 & 2.007871 & $0.079^{*}$ \\
\hline Health risk & 10.71641 & 5 & 2.143282 & 165.6116 & 183 & 0.904982 & 2.368315 & $0.041^{* *}$ \\
\hline Economic risk & 3.99794 & 5 & 0.799588 & 124.8128 & 183 & 0.682037 & 1.172353 & 0.394 \\
\hline Transport risk & 6.13668 & 5 & 1.227335 & 100.8312 & 184 & 0.547995 & 2.239681 & $0.052^{*}$ \\
\hline
\end{tabular}

${ }^{* * *}$ significant at a $1 \%$ level, ${ }^{* *}$ significant at a $5 \%$ level, * significant at a $10 \%$ level

ii) Travel agents are less affected than are lodges by health-associated risks. Although health risks are a discriminatory factor in terms of the types of tourism business included in the survey, this factor has the lowest perceived risk, particularly for travel agents and bed and breakfast establishments. Lodges are most likely to be affected by health risks. Possible reasons for this include closer personal contact with tourists and the location of lodges, which will be elaborated on in section 5 .

iii) Travel agents are more inclined than other tourism businesses, especially bed and breakfast establishments and guesthouses, to regard operational risks as important, presumably because they are more exposed and vulnerable to such risks.

iv) Travel agents are more vulnerable to risks associated with business insufficiencies than guesthouses and are therefore more inclined to regard these risks as more important. This is confirmed when considering the individual risk items associated with business insufficiencies (listed in Table 4).

v) Travel agents rate transport risks as more important than do bed and breakfast establishments and guesthouses. This may be because travel agents are more dependent on transport and are therefore more exposed to such risks.

Tukey's post hoc test on the five factors showed that travel agents are more exposed than other operators or business owners, and are therefore more vulnerable to most risks associated with the tourism industry. The operators or business owners least affected by risk appear to be the bed-and-breakfast establishments and guesthouses. It is therefore important for travel agents to monitor risk continuously and keep their risk management plan up to date. If they implemented appropriate preventive action, travel agents could minimise the negative impact of the risks associated with their business. This applies particularly to those risks regarded as internal to the business, which include operational aspects and business insufficiencies.

\section{5}

\section{Implications for risk management}

Valsamakis et al. (2004) suggest that risk management is an ongoing process, not to be seen in isolation or as a single event. This process starts with risk identification, followed by careful evaluation of the risk to ascertain where control is most necessary, before finally providing financially for the consequences of the risk. To manage a risk, it must first be identified, before any type of risk management programme can be put into action. This part of the process should be viewed as the most important function of the risk management programme and should be approached in a structured, systematic and well-managed manner.

Gray and Larson (2006) also indicate that any risk management process starts with risk identification (see Figure 2). This is then 
followed by risk assessment (or evaluation), before a proper response is developed and a strategy implemented.

The focus of this research was on the first step of this process, risk identification. It was shown that, although most of the literature focuses on identifying external risks, internal risks are an important aspect often overlooked in the South African tourism industry. Two internal risks, operational aspects (factor 1) and business insufficiencies (factor 6), are confirmed by researchers such as Goss (2003) and Saayman and Snyman (2005). The risks captured by these two factors point to key success factors in the tourism industry, since qualified and properly-trained and experienced staff determine the success of a tourism business (Geldenhuys, 2000). The findings of the present study made it clear that most of the internal business risks hinge on skills and staffing matters - in other words, employee risks.

Concerning external risks, the research showed that tourism businesses do not view domestic external risks separately from international ones; they are more inclined to see as external only those risks over which businesses in South Africa have little control. In general, the findings of the research contradicted studies by Cossar (1996), the WHO (2008) and Hadebe (2009), who identify health risk as an important risk facing the industry. In addition, infrastructure is not prominent in the literature, with infrastructure being seen mainly as influencing tourism development rates, but not threatening any risk. However, this research revealed that infrastructure forms an essential part of national image and competitiveness risks and that it is of key importance to the South African tourism industry.

Figure 2

Risk management process

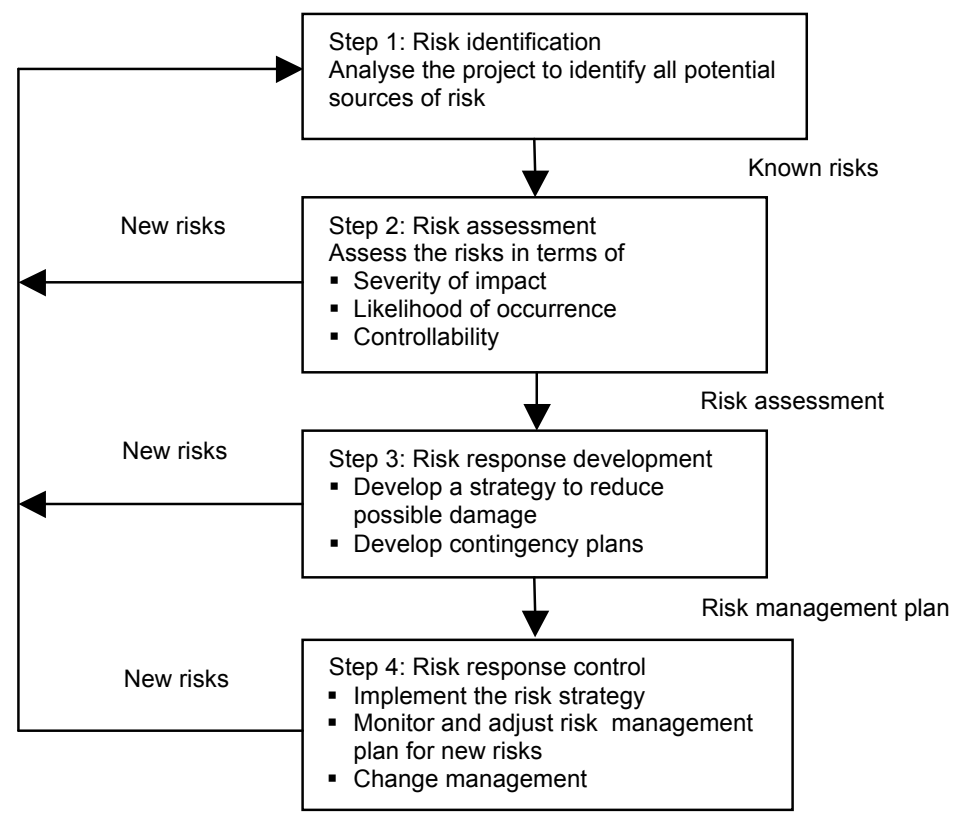

(Source: Adapted from Gray and Larson, 2006:209)

Risks related to economics and competitiveness issues in tourism are well documented, and this research mainly confirmed the findings of, among others, Durbarry and Sinclair (2003), Gu (1995) and Oxelheim and Wihlborg (1998). The same applied to crime and safety and security risks (see Schonteich,
2000). From the results above, as well as from the literature review, it becomes apparent that the risks faced by businesses in developing countries differ from those in developed countries. Most notably, the risk posed by national image and competitiveness (including tourism infrastructure) in developing countries 
like South Africa would in all probability probably not be cited as a major risk in developed countries.

The results also indicated that risks differ for different businesses in the tourism industry. One sector that is more susceptible to risk is the travel agency sector, while accommodation units experience lower levels of overall risk. The only exception here is the health risk, which affects lodges more than travel agents. This might be because lodges are usually located in more natural settings, which are more exposed to health hazards and health legislation. In addition, lodges are more labour-intensive by nature, and the interaction between staff, visitors and owners is more personal, posing increased risk of disease transmission.

The second step in the risk management process is to assess the importance of the risk. One possible method of doing this is to use a risk matrix to classify the risks into the three categories of high, medium and low. The probability of occurrence and the possible consequences were determined using Table 6 as a guideline.

Table 6

Probability and consequence of occurrence

\begin{tabular}{|c|l|c|l|}
\hline \multicolumn{2}{|c|}{ Probability } & \multicolumn{1}{c|}{ Consequence } \\
\hline 6 & Regular (>80\% chance) & 6 & Extremely high cost or loss of life \\
\hline 5 & Probable $(60-79 \%$ chance $)$ & 5 & High cost or serious injuries \\
\hline 4 & Can happen $(40-59 \%$ chance $)$ & 4 & Moderate cost or moderate injuries \\
\hline 3 & Low likelihood $(20-39 \%$ chance) & 3 & Low cost or minor injuries \\
\hline 2 & Rare $(6-19 \%$ chance $)$ & 2 & Extremely low cost or no injuries \\
\hline 1 & Highly unlikely $(<5 \%$ chance $)$ & 1 & No cost or near miss \\
\hline
\end{tabular}

The risk assessment matrix in Figure 3 was used to classify the severity of each risk as high (8-11), medium (5-7) or low (1-4). The severity ranking in the matrix is a logical derivation from the ranking of occurrence and consequence. Starting in the top right-hand corner with the highest ranking of 11 , which is derived from a probability rating of 6 and a consequence rating of 6 , the severity ratings are then decreased by 1 for each square, moving from top to bottom in the right-hand column and then left to right in the top row as the risk severity decreases. The lowest severity risk has a matrix ranking of 1 (bottom lefthand corner).

High severity risks $(8-11)$ require immediate action to eliminate them or at least reduce the possibility of risk or its impact. For medium severity risks (5-7), preventive measures should be implemented. Risks in the low severity category (1-4) do not require action in the immediate future and can be accepted, but personnel ought to be aware of them.

Since travel agency sector clearly differs from the accommodation sector in the tourism industry, a typical risk assessment matrix for travel agents would look as follows, based on the results of this research. Since the questionnaire did not assess the probability of the event or its severity, this matrix is based solely on the importance ranking. Future research on the probabilities and severity of the various risks would improve the matrix. Travel agents rated health risks (factor 7) as the lowest in importance, with an average score of 1.81. Five factors obtained an average importance score of between 2 and 3 on the Likert scale and are therefore viewed as risks with a medium level of severity. These risks were environmental (factor $2-2.33$ ), operational (factor $1-2.53$ ), crime and political (factor 4 2.76), national image and competitiveness (factor $5-2.95$ ) and transport (factor 9 2.95). The remaining three factors scored an average above 3 , which warrants their being placed in the category of risks with consequences of high severity. Travel agents view affordability and safety (factor 3 ) as the most important risk, assigning an average of 3.59 to the items that comprise this risk. It therefore takes top place in the risk assessment matrix (see Figure 4). 
Given the information in Table 4, it is evident that the risks requiring the full and continuous attention by management in travel agencies are affordability and safety, economic risks and business insufficiencies. Strategies for controlling these risks and contingency plans to deal with them should be in place.
These are followed by infrastructure and transport risks, crime and political risks and operational risks. Management should ensure that proper responses to these risks are formulated and in place so that the business will be prepared to deal with problems if they arise.

Figure 3

Risk assessment matrix

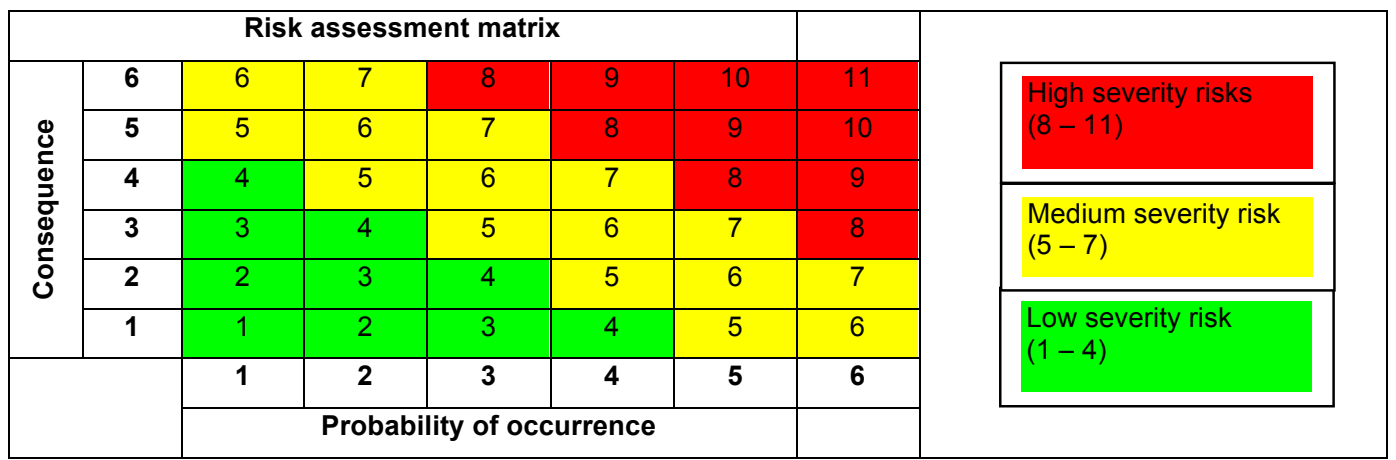

Source: Compiled by authors

\section{Figure 4}

Risk assessment matrix for travel agents

\begin{tabular}{|c|c|c|c|c|c|c|c|}
\hline \multicolumn{7}{|c|}{ Risk assessment matrix } & \\
\hline \multirow{6}{*}{ 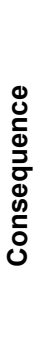 } & 6 & & & & & & \\
\hline & 5 & & & & Economic & $\begin{array}{c}\text { Affordability \& } \\
\text { safety }\end{array}$ & \\
\hline & 4 & & & Crime \& political & $\begin{array}{c}\text { National image \& } \\
\text { competitiveness } \\
\text { Transport }\end{array}$ & $\begin{array}{c}\text { Business } \\
\text { insufficiencies }\end{array}$ & \\
\hline & 3 & & & Environmental & Operational & & \\
\hline & 2 & & Health & & & & \\
\hline & 1 & & & & & & \\
\hline & & 1 & 2 & 3 & 4 & 5 & 6 \\
\hline & & \multicolumn{5}{|c|}{ Probability of occurrence } & \\
\hline
\end{tabular}

Source: Compiled by authors

The following implications are evident. Firstly, while most research has focused on external risks, this research found that two internal risk categories were the most important in the tourism industry. There should therefore be greater focus on addressing internal risks, as they are within a business's ambit for dealing with them. This would, however, require tourism businesses to develop specific skills and acquire specific knowledge on issues pertaining to financial management, market trends, market analysis and management skills. In this regard, the tourism industry should work more closely with training institutions in order to address the risk posed by skills shortages and insufficiently skilled or unskilled staff. Continuous education and training should be a priority for businesses and training institutions. This is of the utmost importance, since most of the internal risks involve employee risks.

Secondly, the results revealed that tourism 
businesses and the different levels of government will have to cooperate more closely if businesses are to proactively address various external risks. The issue of national image and competitiveness is a case in point. The results for this risk suggest that the current systems or institutional arrangements (i.e. government, business councils and private operators) are not fully inclusive. Aspects like basic infrastructure, high levels of safety and security and the need for marketing should be addressed by government, but in collaboration with the industry. Additionally, it is also critical for the owners and managers of tourism businesses to be kept informed of developments. The respondents in this study were all members of very active and well-organised organisations. If they are unaware of developments in these areas, it implies that those who do not belong to any such organisations will be even worse prepared to deal with external risks.

Thirdly, it is evident that the severity of the risks for the various sectors of the industry differs. There is therefore a need for both continuous research and sector-specific solutions that cater for each sector. While other industries, such as banking and insurance, have risk management officers to address risks and have strategies and plans in place, this is not yet standard practice in the tourism industry, despite the industry's susceptibility to risk.

\section{6}

\section{Conclusion}

The purpose of this article was to identify risks that tourism businesses in South Africa deem important and to determine the extent to which different businesses are challenged by different risks. With this information, the first two steps in the risk management process of tourism businesses are addressed.

This research contributes to the field by being one of a handful of studies looking at risk holistically, identifying the important risks and obtaining insight into how tourism businesses (the supply-side) rate the different risks. The research indicated that risk management in tourism is a complex issue, with internal and various external risks that have to be taken into consideration.

The results of the factor analysis identified nine risk factors, two of which were internal and seven external. The literature review revealed that most risk management in tourism takes place reactively. To promote proactive risk management, this research proposes greater co-operation between the industry and training institutions on the one hand and industry and government on the other. In addition, previous research has focused mainly on external risks, whereas this research shows that internal risks faced by businesses in the industry are among the most important. The research therefore proposes that the tourism industry be better equipped to deal proactively with risks.

Finally, this research found that the importance of various risks differs for different sectors in the tourism industry. This requires further research efforts, as not all the sectors were addressed in this research, and strategies on how to deal with risks would also differ. Further research could include analysing and comparing the risks faced by businesses in developed and developing countries. Furthermore, analysis of the probability of an event occurring and the corresponding severity of the event should improve the results of the risk assessment matrix.

\section{References}

ABBOTT, P.L. 1996. Natural disasters, Chicago, Ill.: Brown.

AZIZ, H. 1995. Understanding attacks on tourists in Egypt. Tourism Management, 16:91-95.

BAR-ON, R.R. 1996. Measuring the effects on tourism of violence and of promotion following violent acts, In: Pizam, A. and Mansfeld, Y. (eds.) Tourism, crime and international security issues, New York: Wiley. BRUNT, P., MAWBY, R. \& HAMBLY, Z. 2000. Tourist victimisation and the fear of crime on holiday. Tourism Management, 21(4):417-424.

BURNS, P. 1999. Paradoxes in planning: tourism elitism or brutalism? Annals of Tourism Research, 26: 329-348. 
BUSINESS DAY. 2004. Tourism leads to job-creation change, Business Day, October 22, 2004. Available at: Rastafarispeaks.com website: www.rastafarispeaks.com/cgi-bin/forum/archive1/config.pl?read=45945 (accessed 2010).

CARTER, S. 1998. Tourists' and travellers' social construction of Africa and Asia as risky locations. Tourism Management, 19:349-358.

COOPER, D.R. \& SCHINDLER, P.S. 2001. Business research methods $\left(7^{\text {th }}\right.$ ed.) Boston, Mass.: McGrawHill Irwin.

COSSAR, J.H. 1996. Travellers' health: a medical perspective, In: Clift, S. and Page, S.J. (eds.) Health and the International Tourist, London: Routledge.

COSSENS, J. \& GIN, S. 1994. Tourism and AIDS: the perceived risk of HIV infection and destination choice. Journal of Travel and Tourism Marketing, 3(4):1-20.

DIMANCHE, F. \& LEPTIC, A. 1999. New Orleans tourism and crime: a case study. Journal of Advertising Research, 36(2):69-76.

DORF, R.C. \& BYERS, T.H. 2008. Technology ventures: from idea to enterprise ( $2^{\text {nd }}$ ed.) Boston, Mass.: McGraw-Hill.

DURBARRY, R. \& SINCLAIR, M.T. 2003. Market share analysis: the case of a French tourism demand. Annals of Tourism Research, 30(4):927-941.

DWYER, L., FORSYTH, P. \& RAO, P. 2000. The price of competitiveness of travel and tourism: a comparison of 19 destinations. Tourism Management, 21(9):22.

EHMER, P. \& HEYMANN, E. 2008. Climate change and tourism: where will the journey lead? Available at: Frankfurt am Main, Germany, Deutsche Bank Research website]: www.dbresearch.com/PROD/DBR_ INTERNET_EN-PROD/PROD0000000000222943.pdf (accessed 2007-11-25).

ELLIS, R. 1995. A response to crime's war on tourism. Visions in Leisure and Business, 14(3):52-60.

ENDERS, W., SANDLER, T. \& PARISE, G.F. 1992. An econometric analysis of the impact of terrorism on tourism. Kyklos, 45:531-555.

FIELD, A. 2005. Discovering statistics using SPSS (2 ${ }^{\text {nd }}$ ed.) London: Sage.

GARCIA, R. \& NICHOLLS, L. 1995. Crime in new tourism destinations: the mall of America. Visions in Leisure and Business, 14(4):15-27.

GELDENHUYS, S. 2000. Career profiles for the travel sector of the tourism industry, Magister Commercii dissertation, Potchefstroom University, Potchefstroom, South Africa.

GOSS, P. 2003. The physical inspection: your first line of defense. Available at: CRM Global website]: www.crmglobalinc.com/physical_inspection.htm (accessed 2009-11-12).

GRAY, C.F. \& LARSON, E.W. 2006. Project management: the managerial process $\left(3^{\text {rd }}\right.$ ed.) Boston, Mass.: Irwin/McGraw-Hill.

GU, Z. 1995. The relationship between interest rate and tourism activities. International Journal of

Hospitality Management, 14(3/4):293-243.

HADEBE, F. 2009. Cholera death toll in South Africa rises. Available at: Mail and Guardian online website: www.mg.co.za/article/2009-01-14-cholera-death-toll-in-south-africa-rises (accessed 2009-11-25).

HALL, C., SELWOOD, J. \& MCKEOWN, E. 1995. Hedonists, ladies and larrikins: crime, prostitution and the 1987 America's cup. Visions in Leisure and Business, 14(3):28-51.

HILL, C.W.L. 2002. International business: competing in the global marketplace-postscript $2002\left(3^{\text {rd }}\right.$ ed.) New York: McGraw-Hill Irwin.

HYSTAD, P.W. \& KELLER, P.C. 2008. Towards a destination tourism disaster management framework: long-term lessons from a forest fire disaster. Tourism Management, 29(1):151-162.

JACOBSON, J., BOOCH, G. \& RUMBAUGH, J. 1999. The unified software development process, New York: Addison-Wesley.

JORDAN, E. \& SILCOCK, L. 2005. Beating IT risks, New York: Wiley.

KERZNER, H. 2001. Project management: a systems approach to planning, scheduling, and controlling $\left(7^{\text {th }}\right.$ ed.) New York: Wiley.

KRIPPENDORF, J. 1987. Ecological approach to tourism marketing. Tourism Management, 8(2):174-176.

LAWTON, G. \& PAGE, S. 1997. Evaluating travel agents' provision of health advice to travellers, Tourism Management, 18:89-104. 
LEPP, A. \& GIBSON, H. 2003. Tourist roles, perceived risk and international tourism. Annals of Tourism Research, 30(3):606-624.

LESLIE, D. 1999. Terrorism and tourism: the Northern Ireland situation - a look behind the veil of certainty. Journal of Travel Research, 38(1):37-40.

MET OFFICE. 2007. Clearer: make a difference with the facts about climate change. Available at: Met Office UK website]: www.metoffice.gov.uk/climatechange/guide/downloads/Your\%20Guide_Facts_ The\%20Big\%20Picture_pdf.pdf (accessed 2010-09-24).

MOFFETT, M., STONEHILL, A. \& EITEMAN, D. 2008. Fundamentals of multinational finance ( $3^{\text {rd }}$ ed.) Boston, Mass.: Pearson Prentice Hall.

MOLL, M. 2008. Fire, a keystone ecological process. Earth laughs in flowers. Available at: VeldFlora website]: www.veldfloraed.blogspot.com/2008/.../veld-flora-subject-index-for-2008.html (accessed 2008-11-13).

MOORE, K. \& BERNO, T. 1995. Relationships between crime and tourism. Visions in Leisure and Business, 14(4):4-14.

NATIONAL HURRICANE CENTER. 2005. Home webpage. Available at: NHC website]: www.nhc.noaa.gov/ (accessed 2008-10-08).

NTULI, Z. 2005. Move to regulate taxi industry. Available at: South Africa.info website: www.southafrica.info/what_happening/news/taxidrivers.htm (accessed 2008-08-01).

NXUMALO, F. 2009. SA job losses have doubled due to recession, SABCNews, 13 August 2009. Available at: SABC News website: www.sabcnews.com/portal/site/SABCNews/menuitem.

5c4f8fe7ee929f602ea12ea1674daeb9/?vgnextoid=4df14d36a1213210VgnVCM10000077d4ea9bRCRDandvg nextfmt=default\&channelPath=Economy\%20\%3E\%3E\%20Business (accessed 2010-01-12).

OXELHEIM, L. \& WIHLBORG, C. 1998. Managing in the turbulent world economy: corporate performance and risk exposure, New York: Wiley.

ÖZÜKAN, F.T. 2009. Tourism to offer remedy for unemployment with 300,000 new recruits. Available at: Today's Zaman website]: www.todayszaman.com/tz-web/detaylar.do?load=detay\&link=172223\&bolum=105 (accessed 2009-11-11).

PAGE, S.J. 2007. Tourism management: managing for change, Oxford: Butterworth-Heinemann.

PALLANT, J. 2007. SPSS survival manual: a step by step guide to data analysis using SPSS for Windows $\left(3^{\text {rd }}\right.$ ed.) New York: McGraw-Hill.

PIZAM, A., TARLOW, P.E. \& BLOOM, J. 1997. Making tourists feel safe: Whose responsibility is it? Journal of Travel Research, 36(1):23-28.

PUBLIC HEALTH AGENCY OF CANADA. 2009. Cholera in Zimbabwe. Available at: MyTravelling.com website: www.mytravelling.com/travel_updates (accessed 2010-02-08).

RAVAL, V. \& FICHADIA, A. 2007. Risks, controls, and security: concepts and applications, New York: Wiley.

RAYNER, J. 2003. Managing reputable risk: curbing threats, leveraging opportunities, Chichester, UK: Wiley.

RAYNOR, P. \& ROBINSON, G. 2005. Rehabilitation, crime and justice, Basingstoke: Palgrave Macmillan.

RIA NOVOSTI. 2010. Moscow subway bombings kill 38. available at: Ria Novosti website]: http://en.rian.ru/ Russia/20100329/158352755.html (accessed 2010-04-07).

RICHTER, L.K. \& WAUGH, L.W. Jr. 1986. Terrorism and tourism as logical companions. Tourism Management, 7:230-238.

RIFAI, T. 2009. UNWTO calls on tourism stakeholders to join 'Roadmap for Recovery'. Available at: from eTurboNews website]: www.eturbonews.com/8222/unwto-calls-tourism-stakeholders-join-roadmap-recovery (accessed 2009-11-11).

SAAYMAN, M. 2008. En route with tourism: an introductory text, Potchefstroom: Leisure C Publishers. SAAYMAN, M. \& SNYMAN, J.A. 2005. Entrepreneurship tourism style, Potchefstroom: Leisure C Publishers.

SAWS (South African Weather Service). 2008. Severe weather precautions: tornadoes. safety tips for tornadoes. Available at: South African Weather Service website]: www.weathersa.co.za/Education/ precTornadoes.jsp (accessed 2009-01-26). 
SCHONTEICH, M. 2000. South Africa's position in Africa's crime rankings. African Security Review, 9(4): 51-65.

SHAW, G.K. 2010. A risk management model for the South African tourism industry, Doctoral thesis, North West University, Potchefstroom, South Africa.

SMITH, D. 2006. Exploring innovation, London: McGraw-Hill.

SÖNMEZ, S. 1998. Tourism, terrorism and political instability, Annals of Tourism Research, 25:416-456.

SÖNMEZ, S. \& GRAEFE, A. 1998. Influence of terrorism risk on foreign tourism decisions. Annals of Tourism Research, 25:112-144.

SÖNMEZ, S., APOSTOLOPOULOS, Y.\& TARLOW, P. 1999. Tourism in crisis: managing the effects of terrorism. Journal of Travel Research, 38:13-18.

SPSS Inc. 2007. SPSS ${ }^{\circledR} 16.0$ for Windows, Release 16.0.0, Copyright $\odot$ by SPSS inc., Chicago: Illinois.

STATE, M. \& NEDELEA, A. 2008. The demographic ageing and consumer market, Journal of the Faculty of Economics, XVII. Available at: Journal of the Faculty of Economics website]: http://ssrn.com/abstract=1268264 (accessed 2010-04-07).

TRETHEWAY, M. \& MAK, D. 2006. Emerging tourism markets: ageing and developing economies. Journal of Air Transport Management, 12:21-27.

UN (United Nations). 2005. Sudden onset disaster coordination activities, Part IV, Available at: Office for the Coordination of Humanitarian Affairs website]: http://ochaonline.un.org/ocha2005/Pt\%20IV\% 20tsunami.htm (accessed 2006-08-18).

UNISDR (International Strategy for Disaster Reduction). 2009. What is risk? Available at: UNISDR website: http://www.unisdr.org/eng/public_aware/world_camp/2004/booklet-eng/Pagina9ing.pdf (accessed 2008-11-13).

UNWTO (World Tourism Organisation). 2009. World Tourism Barometer, 7(2) June 2009.

USAID. 2009. Report to congress: health-related research and development activities at usaid - an update of the five-year strategy, 2006-2010, September 2009, Washington D.C.: US Agency for International Development.

VALSAMAKIS, A.C., VIVIAN, R.W. \& DU TOIT, G.S. 2004. Risk management: managing enterprise risks $\left(3^{\text {rd }}\right.$ ed.) Sandton: Heinemann.

VELLAS, F. \& BECHEREL, L. 1995. International tourism: an economic perspective, New York: Palgrave. WAGNER, S., APOSTOLOPOULOS, Y. \& TARLOW, P. 1999. Tourism in crisis: managing the effects of terrorism. Journal of Travel Research, 38:13-18.

WHO (World Health Organisation). 2006. Ebola haemorrhagic fever. Available at: WHO website]: www.who.int/mediacentre/ factsheets/fs103/en/ (accessed 2010-04-08).

WHO (World Health Organisation). 2008. Cholera. Available at: WHO website]: www.who.int/mediacentre/ factsheet/fs107/en/ index.html (accessed 2009-01-05).

YAMANE, T. 1967. Statistics: an introductory analysis ( $2^{\text {nd }}$ ed.) New York: Harper and Row. 